\title{
Pediatri Hemşirelik Öğrencilerin Çocuk Sevme Düzeyleri ile Duygusal Emek Davranışları, Uygulama Performansları Arasındaki İlişki
}

\author{
Relationship Between Liking of Children and Emotional Labor Behaviors, Clinical Performances in Pediatric \\ Nursing Students
}

Fadime ÜSTÜNER TOP ${ }^{1}$

\begin{abstract}
ÖZ
Araştırma, pediatri hemşirelik öğrencilerin çocuk sevme düzeyleri ile duygusal emek davranışları, uygulama performansları arasındaki ilişkinin belirlenmesi amacıyla yapıldı. Araştırma tanımlayıcı tipte, ilişkisel tarama modelli olarak yapıldı. Örneklemi pediatri dersi alan hemşirelik bölümü öğrencileri $(n=127)$ oluşturdu. Veriler; Bireysel Tanıtım Formu, Çocuk Sevme Ölçeği ve Duygusal Emek Davranış Ölçeği ile toplandı. Araştırmada öğrenci-eğitici etkileşimini önlemek amacı ile veriler bir anketör tarafindan toplanarak bilgisayar ortamına

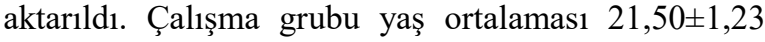
olup, \%84,7'sinin hemşirelik mesleğini sevdiği, \%91,1'inin çocuk oyunlarını bildiği, \%59,7'sinin çocuk kitapları okuduğu \%38,7'sinin çalışma hayatında çocuk servisinde çalışmayı istediği tespit edildi. Barnett's Çocuk Sevme Ölçeği puan ortalaması $80,27 \pm 13,40$, Duygusal Emek Davranışı Ölçeği puan ortalaması 2,98 $\pm 0,44$ 'dır. Çocuk Sevme Ölçeği puan ortalamaları incelendiğinde cinsiyetin, lise tipinin, çocuk kitapları okumak, çocuk servisinde çalışmak isteme durumunun etkili olduğu belirlendi. Öğrencilerin klinik uygulama puanlarıyla; Çocuk Sevme Ölçeği puanları arasında pozitif yönde orta düzeyde, 'Samimi davranış' alt boyut puanı ile arasında pozitif yönde yüksek düzeyde anlamlı bir ilişki olduğu saptand1. Çalışmada öğrenci hemşirelerin çocukları sevme durumunun yüksek olduğu sonucuna varıldı. Çocuk sevme düzeyinin klinik uygulama puanı ve duygusal emek davranışını etkilediği saptandı. Öğrenci hemşirelerinin çocuk sevme düzeyine katkı sağlayacak faaliyetler ile pediatri klinik performansları güçlendirilebilir.
\end{abstract}

Anahtar Kelimeler: Pediatri, Öğrenci hemșire, Duygusal, Klinik Uygulama

\begin{abstract}
The study was planned to determine the relationship between the liking of children level of pediatric nurses students and their emotional labor behaviors, their clinic performance.The research was planned as a descriptive, relational scanning model. The nursing department students $(n=127)$ taking pediatrics course constituted the sample. Data was collected using The Individual Information Form, Barnett Liking of Children Scale and Emotional Labor Behavior Scale. The study in order to prevent studenteducator interaction, the data were collected by an interviewer. The average age was $21.50 \pm 1.23$, it was determined that $84.7 \%$ liked the profession, $91.1 \%$ knew children's games, $59.7 \%$ read children's books, $38.7 \%$ wanted to work in the pediatric clinic their life. Barnett Liking of Children Scale mean score is $80.27 \pm 13.40$, Emotional Labor Behavior Scale mean score is $2.98 \pm 0.44$. When the mean scores of the Liking of Children Scale were examined, it was determined that gender, type of high school wanting to read children's boks and work in the pediatric clinic were effective. It was determined that there is a moderate positive correlation between the clinical practice scores of the students the Liking of Children Scale scores, and a high level of positive correlation with the 'Genuine Acting' sub-dimension scores. It was concluded that student nurses have a high liking for children. It was determined that the level of child liking affected the clinical practice score and emotional labor behavior. The pediatric clinical performances of nurse students can be strengthened by activities that will contribute to the level of liking of children.
\end{abstract}

Keywords: Pediatric, Nursing students, Emotional, Clinic Activities 


\section{GíRiş}

Hemşirelik eğitimi, hemşirelik öğrencilerine karmaşık sağlık sorunları olan hastalara uygun klinik deneyimlerle en iyi kalitede bakım sunmaları için gerekli olan beceriler geliştirmeyi sağlamaktadır. ${ }^{1} \mathrm{Bu}$ eğitim teorik ve klinik uygulamayı içeren iki ana unsurdan oluşmaktadır. Klinik deneyim, hemşirelik öğrencilerini güvenli ve kaliteli bakım sağlamak için gerekli becerilerle hazırlayan, hemşirelik eğitiminde lisans öğreniminin temel bir unsuru olarak kabul edilir. $^{2}$

Klinik uygulama alanı hemşirelik öğrencileri için önemli bir öğrenme ortamı olup, geleneksel sınıf ortamlarının aksine, klinik eğitim karmaşık bir sosyal alanda gerçekleşmektedir. Hemşire öğrencilerinin klinik yeterlilikleri ve profesyonel kimlikleri bu ortamda oluşmaktadır. Diğer taraftan klinik ortamdaki birçok faktör etkin eğitimin sağlanmasında güçlük yaşanmasına neden olarak öğrenmeyi olumsuz etkileyebilmektedir. ${ }^{3}$ Literatürde öğrenci hemşirelerin teori ve pratik arasındaki boşluklar nedeniyle klinik uygulamada sıklıkla birçok zorlukla karşılaştığı ve sürecin yoğun stresli olabileceğini belirten sonuçlar bulunmaktadır. Tüm bunlar öğrencinin endişesini artırırken vereceği bakımın kalitesine de olumsuz etki etmektedir. Özellikle pediatri uygulama alanı çalışma grubunun gelişimsel ihtiyaçlarındaki değişimlerle ve birden fazla aile üyesi ile çalışmanın zorlukları ile ilgili karmaşıklıklar nedeniyle hemşirelik öğrencilerin eğitimleri süresince en fazla stres ve endişe yaşadıkları kliniktir., ${ }^{4,5}$ Pediatri kliniğinde çalışan ögrenciler bir yandan umut, sevgi, güvenlik ve mutluluk gibi olumlu duygular diğer yandan da öfke, korku, endişe, stres, güçsüzlük gibi olumsuz duygular hissedebilmektedir. ${ }^{6}$ Klinik eğitim sırasında olumlu duyguların yaşanması öğrencileri motivasyon ve öğrenme becerilerini arttırırken $^{7}$, olumsuz duygular yaşanması öğrenme ve bakım verme motivasyonunu azaltmaktadır. ${ }^{8}$ Pediatri hemşiresi olmak, çocukları sevmekle başlamaktadır. ${ }^{9}$ Pediatri kliniklerinde çalışan öğrenciler çocuklara sevgi duyarsa, bu durum öğrencilerde olumlu duygulara yol açabilir. Aksi bir durumda eğitim için motive edici bir ortamın yaratılmasını ve pediatri kliniklerindeki eğitimden beklenen sonuçların elde edilmesini engelleyebilmektedir.

Hemşirelik mesleğinin ana görevi olan bakımla ilgili uygulamaların her biri belirli bir duygusal emek gerektirir. Duygusal emek davranışı; bireyin kendisinin ve çevresinin duygularını stratejik olarak düzenlemesi olarak ifade edilmekte ve derinlemesine davranış, yüzeysel davranış, samimi davranış alt boyutlarını içermektedir. ${ }^{10}$ Hemşireler işleriyle ilgili güçlü duygular yaşarlar ve bu duygular klinik uygulamalarını şekillendirmektedir. Hemşirelikte duygusal emek davranışları kendilerinin ve bakım verilen bireylerin duygularını nasıl yönettikleri ile anlaşılmaktadır. Süreçte duygusal uyumsuzluk, hemşirelerde strese ve tükenmişliğe yol açan başka bir faktördür. Hemşirelik uygulamalarında duygusal emek davranışlarını açığa çıkarmak hemşirelerin duygusal baskı ve stresle baş edebilmesine firsat sağlamaktadır. Hemşirelerin duygusal emek türü yetenek ve klinik yeterlilikleri ile ilgilidir ve duygusal emek davranışlarının olumlu noktaya getirilmesine yönelik stratejilerin geliştirilmesi gerekmektedir. ${ }^{11}$ $\mathrm{Bu}$ doğrultuda, hem eğitimler hem uygulamalar esnasında hemşirelerin duygusal gereksinimlerinin ihmal edilmemesi, duygusal gereksinimlerine değer verilmesi oldukça önemlidir. ${ }^{12,13}$

Öğrencilerin pediatri kliniği uygulamasına ilişkin deneyimledikleri karmaşık güçlükler onların hem klinik uygulama kalitesini hem de klinik uygulama başarısına açık bir tehdit olarak algılanmaktadır. Öğrencinin istendik teorik bilgi, klinik beceri, mesleki değer ve profesyonel kimliği kazanması öncelikle hemşirelik eğitimi süresince stres olarak algıladığ1 deneyimlerinin anlaşılması ile sağlanabilir. ${ }^{14} \quad$ Literatürde pediatri hemşireleri ve öğrenci hemşirelerin çocuk sevme düzeyleri ve ilişkili faktörlerin bakım kalitesini etkilediği görülmektedir. ${ }^{6,8} 9$ Ancak hemşirelik öğrencilerinin çocuk sevme 
durumlarını, duygusal emek davranışları, uygulama performansı ilişkisi ve ilişkili faktörleri inceleyen çalışma bulunmamaktadır. Bu alana ilişsin eksiklikler öğrencilerin etkin öğrenme durumlarını ve çocuklara sunulan bakımının kalitesini etkileyecek bir faktördür. Araştırma ile hem eğitimcilere rehber olarak hemşirelik öğrencilerinin klinik öğrenme başarısını hem de pediatri kliniğinde sunulan bakım kalitesini arttırmak amaçlandı.
Araştırma, pediatri dersi alan hemşirelik öğrencilerin duygusal emek davranışları, çocuk sevme düzeyleri, uygulama performansları arasındaki ilişkinin belirlenmesi amacıyla yapıldı. Araştırmanın pediatri dersi alan hemşirelik öğrencilerin duygusal emek davranışları, çocuk sevme düzeyleri ve uygulama performansları arasındaki ilişkinin belirlenmesi ile uygulama performansını artıracak eğitim ve girişimlerin geliştirilmesinde yol gösterici olacağı düşünülmektedir.

\section{MATERYAL VE METOT}

\section{Araştırma Tasarımı ve Örneklemi}

Araştırma tanımlayıcı tipte, ilişkisel tarama modelli olarak yapıldı. Araştırma; Karadeniz bölgesinde bulunan bir il merkezinde devlet üniversitesi Sağlik Bilimleri Fakültesinde yürütüldü. Araştırmanın evrenini Sağlık Bilimleri Fakültesinde 2019-2020 Eğitim-Öğretim yılında pediatri dersi alan hemşirelik bölümü öğrencileri oluşturdu. Evrene ulaşılabilirlik dikkate alınarak örneklem seçimine gidilmedi, çalışmanın yapıldığı kurumda, veri toplama tarihlerinde araştırmaya alınma ölçütlerini taşıyan öğrencilerin tamamı $(\mathrm{n}=127)$ çalışmaya dâhil edildi. Pediatri dersi alıyor olmak, çalışmaya katılmaya gönüllü olmak araştırmaya alınma ölçütleridir. Verileri eksik olan 2 öğrenci ile katılmayı kabul etmeyen 1 öğrenci örnekleme dâhil edilmedi ve örneklemin \%97,6'sına ulaşılarak çalışma 124 öğrenci ile tamamlandi.

\section{Araştırmada Kullanılan Araç ve Gereçler}

$\mathrm{Bu}$ araştırmada veri toplama aracı olarak; Bireysel Tanıtım Formu, Barnett's Çocuk Sevme Ölçeği ve Duygusal Emek Ölçeği (DEDÖ) kullanıldı.

Bireysel Tanitim Formu: $\mathrm{Bu}$ form literatürden yararlanılarak araştırmacı tarafindan hazırlandı. ${ }^{8,9,12}$ Formda; öğrencilere ait sosyodemografik bilgiler (yaş, cinsiyet, kardeş sayısı, aile tipi, yaşadığı yer), mesleğe ilişkin bilgiler ve çocuk oyunlarını bilme, çocuk kitapları okuma şeklinde 20 soru yer almaktadir.

Duygusal Emek Davranış Ölçeği (DEDÖ): Ölçek Grandey (1999) ve Bratheridge ve Lee'nin (1998) geliştirdiği ölçeğin formları Türkçeye uyarlanan geçerlilik, güvenilirliği bulunmaktadır. Duygusal Emek Davranışı Ölçeği Değirmenci Öz (2016) tarafından geçerliliği ve güvenilirliği yapıldı ve 3 alt boyutta toplandi. Yüzeysel Davranış Alt Boyutu (6 madde), Derinlemesine Davranış Alt Boyutu (13 madde), Samimi Davranış Alt Boyutu (5 madde). Ölçekte olumsuz madde (ters puanlama) bulunmamaktadır. Ölçek puan değerlendirilmesi, her bir alt boyuta ait alınan puanın toplanması, sonrasinda bu puanın o alt boyuttaki madde sayısına bölünmesi elde edilen aritmetik ortalama ile ifade edilmektedir. Ölçeği oluşturan ifadelerin değerlendirilmesi " 1 - kesinlikle kat1lmiyorum" ve "5- tamamen katıliyorum" olarak tanımlanmaktadır. Ölçek ve alt boyutlarına ilişkin ortalama puanın "1"e yaklaşması duygusal emek davranışının düşük olduğunu, ortalama puanın "5"e yaklaşması ise duygusal emek davranışının yüksek olduğunu ifade etmektedir. ${ }^{15} \mathrm{Bu}$ çalışmada ölçeğin Cronbach's Alpha değeri 0,797, Yüzeysel Davranış alt boyutu Cronbach's Alpha değeri 0,808, Derinlemesine Davranış alt boyutu Cronbach's Alpha değeri 0,772 ve Samimi Davranış alt boyutu Cronbach's Alpha değeri 0,791 olarak bulundu.

Barnett's Çocuk Sevme Ölçeği: Ölçek Barnett ve Sinsini (1990) tarafindan 
geliştirildi. Bireylerin çocukları sevme durumunu değerlendirmek amaciyla geliştirilen ölçeğin Türkçe geçerlilik ve güvenirliliği Duyan ve Gelbal tarafından yapıld1. Ölçekte toplam on dört madde yer almaktadır. Ölçeğin maddelerinde belirtilen ifadelere, bireyler "Hiç katılmıyorum" yanitından, "Tamamen katılıyorum" arasında değişen yedi derecede puan vermektedir. Ölçekte ters kodlanan 4 adet olumsuz madde $(3,6,10,13)$ bulunmaktadır. Ölçekten toplamda elde edilen puanlar 14-98 arasındadır. Ölçekten alınan puanın düşük olması çocukları sevme düzeyinin düşük olduğunu, alınan puanın yüksek olması ise çocukları sevme düzeyinin yüksek olduğunu ifade etmektedir. Barnett's Çocuk Sevme Ölçeği Cronbach's Alpha değeri 0,92 olarak belirlendi. ${ }^{16} \mathrm{Bu}$ çalışmada ölçeğin Cronbach's Alpha değeri 0,932'dir.

\section{Verilerin Toplanması}

Araştırmaya alınma ölçütlerini taşıyan öğrencilere çalışma hakkında bilgilendirme yapılıp onam alındiktan sonra veri toplama aşaması başladı. Araştırmada öğrenci-eğitici etkileșimi önlemek amacı ile veriler bir anketör tarafindan toplanarak bilgisayar ortamına aktarıld1. Veri toplama formlarda isim belirtilmedi ve formlar toplu olarak değerlendirildi. Dönem sonunda bireysel tanıtım formuna ders uygulama performans1 eklenmesi gerektiği için anketlere öğrencilerle eşleştirilmiş numaralar verildi. Anketör tarafından sınıf ortamında, yüz yüze görüşme yöntemi ile "Bireysel Tanıtım Formu", "Duygusal Emek Ölçeği (DEDÖ)" ve "Çocuk Sevme Ölçeği" kullanılarak veriler toplandı. Anketör tarafından dönem sonunda bireysel tanitım formuna ders uygulama performans1 eklendi. Anket formu yaklaşık 15-20 dakikada dolduruldu.

\section{Araştırmanın Değişkenleri}

Bağımlı Değişkenler: Katılımcıların duygusal emek davranışları, çocuk sevme düzeyleri ve uygulama performansları bu araştırmanın bağımlı değişkenleridir.
Bağımsız Değişkenler: Katılımcıların cinsiyet, yaş, öğrenim durumu, medeni durum, çocuk olup olmama durumu, çocuk oyunlarını bilme, çocuk kitapları okuma vb. ilişkin özellikleri bu araştırmanın bağımsız değişkenleridir.

\section{Verilerin Değerlendirilmesi}

Toplanan verilerin hata kontrolleri yapılıp, analizler için SPSS 21,0 (Statistical Package for Social Sciences) paket programindan faydalanıldı. Verilerin analizinde sayı ve yüzdelik hesapları, aritmetik ortalama gibi tanımlayıcı istatistiksel yöntemleri kullanıldı. Verilerin normallik durumunun belirlenmesi için Kolmogorov-Smirnov dağılım testi uygulandi. Gruplar arasında normal dağılım gösteren değişkenlerin karşılaştırılması için bağımsız gruplarda $t$ testi, One-Way ANOVA; sayısal değişkenler arasındaki ilişki için ise pearson korelasyon analizi kullanıldı. İstatistiksel anlamlılık düzeyi olarak $\mathrm{p}<0.05$ alınd 1 .

\section{Araştırmanın Etik Boyutu}

Araştırmanın yürütülmesi için Etik Kurul onay1 Giresun Üniversitesi Etik Komite Kurulu'ndan (2020/6 sayıl1) alındı. Araştırma için kurum izni, alındıktan sonra Çocuk Sağlığı ve Hastalıkları Hemşireliği dersi alan öğrencilere araştırma hakkında bilgi verilip gönüllülük ilkesi doğrultusunda sözel onamları alındı. Veri toplama aracı olarak kullanılan ölçeklerin kullanımına ilişkin gerekli izin bilgisi elektronik posta yoluyla alınd. Helsinki deklerasyonu ilkeleri kapsamında katılımcılar araştırmanın amacı, yöntemi hakkında yazılı olarak bilgilendirildi.

\section{Araştırmanın Sınırlılıkları}

Araştırmanın, verilerin toplandığı okul ve öğrenciler ile yapılması bir sinırlılıktır. $\mathrm{Bu}$ yüzden, araştırmadan elde edilen sonuçlar, bu araştırma grubundaki hemşirelik bölümü öğrencilerine genellenebilir. 


\section{BULGULAR VE TARTIȘMA}

Öğrencilerin yaş ortalamaları $21,50 \pm 1,23$ y1l (min: 20, max:26) olup, \%70,2'si kadındır. Katılımcıların \%87,9'unun düz lise mezunu olduğu, \%95,2'sinin kardeşinin olduğu, \%79,8'inin çekirdek ailede yaşadı ğı, $\% 50$ 'sinin il merkezinde yaşadığ 1 , $\% 78,2$ 'sinin orta düzeyde gelire sahip olduğu ve \% 67,7'sinin akademik başarılarını 'orta seviyede' olarak değerlendirdikleri belirlendi. Öğrencilerin \%84,7'sinin hemşirelik mesleğini sevdiği, \%60,5'inin mesleği kendi isteği ile seçtiği, \%54,8'inin bugün seçme şans1 olsaydı yine hemşirelik mesleğini seçeceği saptand1. Öğrencilerin \%91,1'inin çocuk oyunlarını bildiği, $\% 59,7$ 'sinin çocuk kitapları okuduğu \%38,7'sinin çalışma hayatında çocuk servisinde çalışmayı istediği tespit edildi (Tablo 1).

Tablo 1. Öğrencilerin demografik özelliklerinin dağılımı (N=124)

\begin{tabular}{|c|c|c|}
\hline Tanıtıcı Bilgiler & $\mathrm{n}$ & $\%$ \\
\hline Uygulama performansı (Ort. \pm SS) & $74,17 \pm 9,84$ (min: $50, \max : 92)$ & \\
\hline \multicolumn{3}{|l|}{ Cinsiyet } \\
\hline $\mathrm{K}_{1 \mathrm{Z}}$ & 87 & 70,2 \\
\hline Erkek & 37 & 29,8 \\
\hline \multicolumn{3}{|l|}{ Mezun olunan lise } \\
\hline Düz lise & 109 & 87,9 \\
\hline Sağlık meslek lisesi & 15 & 12,1 \\
\hline \multicolumn{3}{|l|}{ Kardeş durumu } \\
\hline Evet & 118 & 95,2 \\
\hline Hayır & 6 & 4,8 \\
\hline \multicolumn{3}{|l|}{ Aile tipi } \\
\hline Çekirdek & 99 & 79,8 \\
\hline Geniș & 25 & 4,8 \\
\hline \multicolumn{3}{|l|}{ Yașanılan yer } \\
\hline İl & 62 & 50 \\
\hline İlçe & 44 & 35,5 \\
\hline Köy & 18 & 14,5 \\
\hline \multicolumn{3}{|l|}{ Ekonomik durum } \\
\hline İyi & 23 & 18,5 \\
\hline Orta & 97 & 78,2 \\
\hline Kötü & 4 & 3,2 \\
\hline \multicolumn{3}{|l|}{ Hemşireliği sevme durumu } \\
\hline Evet & 105 & 84,7 \\
\hline Hayır & 19 & 15,3 \\
\hline \multicolumn{3}{|l|}{ Hemşireliği isteyerek seçme durumu } \\
\hline Evet & 75 & 60,5 \\
\hline Hayır & 49 & 39,5 \\
\hline \multicolumn{3}{|c|}{ Bugün seçme şansı olsa yine hemşireliği seçme durumu } \\
\hline Evet & 68 & 54,8 \\
\hline Hayır & 56 & 45,2 \\
\hline \multicolumn{3}{|l|}{ Çocuk oyunlarını bilme durumu } \\
\hline Evet & 113 & 91,1 \\
\hline Hayır & 11 & 8,9 \\
\hline \multicolumn{3}{|l|}{ Çocuk kitapları okuma durumu } \\
\hline Evet & 74 & 59,7 \\
\hline Hayır & 50 & 40,3 \\
\hline \multicolumn{3}{|c|}{ Meslek hayatında çocuk servisinde çalışma durumu } \\
\hline Evet & 48 & 38,7 \\
\hline Hayır & 76 & 61,3 \\
\hline \multicolumn{3}{|l|}{ Akademik bașarı değerlendirme } \\
\hline İyi & 34 & 27,4 \\
\hline Orta & 84 & 67,7 \\
\hline Kötü & 6 & 4,8 \\
\hline
\end{tabular}


Çalışmamızda öğrencilerin Barnett's Çocuk Sevme Ölçeği puan ortalamasının 80,27 $\pm 13,40 \quad$ (min:43; max.98) olduğu saptandi (Tablo 2). Pediatrik klinik uygulama döneminin sonunda öğrencilerden çocuğun ve ailesinin bakım ihtiyaçlarını karşılamak için gerekli becerileri öğrenmeleri beklenir. Klinik alanda olumlu duygular yaşamak öğrencinin klinik eğitim sürecinde öğrenme başarısını ve istekliliğini arttırırken, olumsuz duygular ise klinik eğitim sürecinde öğrenme başarısını ve istekliliğini azaltmaktadır. ${ }^{7,8}$ Pediatrik klinik uygulama döneminde öğrenci hemşirelerin olumlu duygular yaşayıp yaşamadığını etkileyen faktörlerden biri de çocukları sevmektir.

Tablo 2. Öğrencilerin Barnett's Çocuk Sevme Ölçeği ve Hemşireler İçin Duygusal Emek Davranışı Ölçeği puan ortalamaları

\begin{tabular}{llll}
\hline Ölçek & n & Ort. \pm SS & Min-Mak \\
Barnett's Çocuk Sevme Öıçeği & 124 & $80,27 \pm 13,40$ & $43-98$ \\
Hemşireler İçin Duygusal Emek Davranışı Öıçeği & 124 & $2,98 \pm 0,44$ & $1,88-4,17$ \\
$\quad$ & 124 & $2,88 \pm 0,55$ & $1,69-4,38$ \\
$\quad$ Derinlemesine Davranış & 124 & $2,93 \pm 0,57$ & $1,50-4,83$ \\
$\quad$ Yüzeyel Davranış & 124 & $3,61 \pm 0,86$ & $1,67-5,00$ \\
$\quad$ Samimi Davranış &
\end{tabular}

Çalışmada öğrenci hemşirelerin çocuk sevme ölçeği ortalama puanlarının yüksek olduğu görülmektedir. Barnett Çocukları Sevme Ölçeğinden alınabilecek puanlar 14 ile 98 arasındadır ve yüksek puanlar insanların çocukları daha çok sevdiği anlamına gelmektedir. ${ }^{16}$ Literatürde birçok çalışmada pediatri alanında çalışan öğrenci hemşirelerin ve pediatri hemşirelerin çocuk sevme ölçeği puan ortalamalarının 82,07 ile 87,11 arasinda değişmekte olduğu görülmektedir. ${ }^{8,17,18-21}$ Çocuk hemşirelerinin çocukların ihtiyaçları olan bakım kalitesi için gelişimsel özelliklerini anlayabilmeleri, onlara gerekli sevgi ve ilgiyi göstermeleri son derece önemlidir.

Öğrencilerin Hemşireler İçin Duygusal Emek Davranışı Ölçeği puan ortalaması 2,98 $\pm 0,44 \quad$ (min:1.88; max.4.17), 'Derinlemesine Davranış' alt boyut puan ortalamasinin 2,88 $\quad 0,55 \quad$ (min:1.69; max.4.38), Yüzeysel Davranış alt boyut puan ortalamasinin 2,93 $\pm 0,57 \quad$ (min:1.50; max.4.83), Samimi Davranış alt boyut puan ortalamasinin 3,61 $\pm 0,86$ (min:1.67; max.5.0) olduğu belirlendi (Tablo 2).

Öğrenci hemşirelerin duygusal emek davranışı ölçeği puanının ortalama düzeylerde olduğu, en yüksek ortalama puanının samimi davranış alt boyutunda, en düşük ortalama puanın derinlemesine davranış alt boyutunda olduğu saptand (Tablo 2). Yıldız'in hemşire grupla çalışmasında, duygusal emek davranışı ölçek genel puan ortalamas1 $(3,94 \pm 0,58)$ çalışmamızdan yüksek olup, yüzeysel davranış alt boyut puan ortalamasının, derin ve samimi davranış alt boyut puan ortalamasından anlamlı olarak daha düşük olduğu belirlendi. Hemşirelerin duygusal emek davranışının orta düzeyin üstünde olduğu, duygusal emek davranışının derinlemesine ve samimi davranış alt boyutlarında daha fazla gösterildiği saptand $1 .{ }^{13}$ Koçak ve arkadaşlarının öğrenci hemşirelerle, Değirmenci'nin hemşirelerle çalışmasında katılımcıların duygusal emek davranışı alt boyutuna ilişkin en s1k derinlemesine davranış, en az bastırma davranışı sergiledikleri belirlendi. ${ }^{15,22}$ Duygusal emek davranışının samimiyet alt boyut puan ortalaması kadınlarda, çocuk kitabı okuyan, mezuniyet sonrası çocuk servisinde çalışmak isteyen öğrencilerde yüksekti. Yüzeysel davranış alt boyut puan ortalaması ise erkeklerde ve mezuniyet sonrası çocuk servisinde çalışmak istemeyenlerde yüksek bulundu. Literatürde duygusal emek davranışı inceleyen çalışma sonuçlarına göre; kadınların erkeklere göre daha samimi duygusal emek davranış1 
sergilediğ $i^{23,24}$, erkek hemşirelerin yüzeysel emek davranışını kadın hemşirelere göre daha fazla sergilediği ${ }^{24}$ görülmektedir. Hemşirelerin uygun durum ve uygun düzeyde duygusal emek davranışı gösterebilmelerini sağlamak amacı ile duygusal emek kavramına yönelik farkındalığın oluşturulması önemlidir.

Tablo 3'te öğrencilerin bazı tanımlayıcı özelliklerine göre Barnett's Çocuk Sevme Ölçeği ve Hemşireler İçin Duygusal Emek Davranışı Ölçeğinden aldıkları puan ortalamaları yer almaktadır. Öğrencilerin cinsiyetlerine göre Barnett's Çocuk Sevme ve Duygusal Emek Davranışı Ölçeği puan ortalamaları incelendiğinde, erkek öğrencilerin derinlemesine davranış $(\mathrm{p}<0,00)$, yüzeysel davranış $(\mathrm{p}=0,001)$ ve ölçek toplam puanlarının $(\mathrm{p}=0,001)$ anlamlı olarak daha yüksek olduğu; kadın öğrencilerin ise samimi davranış $(p<0,000)$ ve Çocuk Sevme Ölçeği puanlarının $(p<0,00)$ anlamlı olarak daha yüksek olduğu saptandı. Sağlık meslek lisesi mezunu $(p=0,031)$ ve çocuk kitapları okuyan öğrencilerin $(\mathrm{p}=0,015)$ Çocuk Sevme Ölçeği puanlarının anlamlı olarak yüksek olduğu bulundu. Çocuk kitapları okuyan öğrencilerin Çocuk Sevme Ölçeği $(p=0,018)$ ve samimi davranış puanlarının $(p=0,004)$; mezuniyet sonras1 çocuk servisinde çalışmak isteyin öğrencilerin Çocuk Sevme Ölçeği $(p<0.000)$, yüzeysel davranış $(p=0,044)$ ve samimi davranış $(\mathrm{p}=0,001)$ puanlarının anlamlı olarak yüksek olduğu bulundu. Tabloda belirtilmemekle birlikte ögrrencilerin kardeş sayısı, aile yapısı, yaşadığı yer, gelir düzeyi, akademik başarı durumu ve hemşirelik mesleğini sevme durumları ile Barnett's Çocuk Sevme Ölçeği ve Hemşireler İçin Duygusal Emek Davranışı Ölçeği puanları arasında ilişki saptanmadı $(\mathrm{p}>0,005)$ (Tablo 3).

Çalışmada öğrenci hemşirelerin çocuk sevme ölçeği ortalama puanlarının kadınlarda, sağlık meslek lisesi mezunu olanlarda, çocuk kitapları okuyan ve mezuniyet sonrası çocuk servisinde çalışmak isteyenlerde yüksek görülmektedir. Bunların çocuk sevmeyi etkilen faktörler olduğu saptand. Çalışma sonucunu destekler nitelikte Baran ve Y1lmaz'ın, Kostak'in çalışmalarında erkek öğrencilerinin çocuk sevme ölçeği puan ortalamasının kadın öğrencilerinin çocuk sevme ölçeği puan ortalamasına göre daha düşük olduğu belirlendi. ${ }^{18,20}$ Bektaş ve arkadaşları (2015) ise çalışmasında cinsiyet faktörünün öğrencilerin çocuk sevme ölçeği puan ortalamasında etkili olmadığı saptandı. Al Ma'aitah ve Gharaibeh (2000) tarafindan Ürdün'de erkek hemşirelik öğrencileri üzerinde yapılan bir çalışmada öğrencilerin mezuniyet sonrası çocuklarla çalışma konusundaki görüşleri incelendi. $\mathrm{Bu}$ araştırmada öğrencilerin erkeklerden ziyade kadınların pediatri hizmetlerinde çalışmasının daha uygun olduğunu düşündükleri ve bu yanlış anlamanın altında yatan en önemli nedenin öğrencilerin sosyokültürel bakıș açıları olduğu belirtildi. ${ }^{25}$ Türk kültüründe çocuk yetiştirmenin kadının sorumluluğu olması ve çocuk yetiştirme rollerinin genellikle kadınlarla ilişkilendirilmesi nedeniyle erkek öğrencilerin daha düşük puanlara sahip olduğu düşünülmektedir. Hemşirelik öğrencileri üzerinde yapılan araştırmalarda çocuk servisinde çalışma isteği ile çocukları sevme arasında anlamlı bir ilişki bulundu. ${ }^{18-}$ 20,26 Yine benzer bir çalışmada Happell; çocuklarla çalışmak isteyen öğrenci hemşirelerin \%85'inin çocukları sevdiği ve çocuklarla çalışmanın en popüler seçenekleri olduğunu buldu. Aynı çalışmada öğrencilik sürecinde çocuklarla çalışmayı seven öğrencilerin mezuniyet sonrası dönemde pediatri kliniklerinde çalışmayı istedikleri saptand1. ${ }^{9}$ Kariyer seçiminde çocuklardan hoşlanmanın en hayati değişken olduğunu ve çocuklarla zaman geçirmeyi seven öğrencilerin gelecekteki kariyerlerinde çocuklarla çalışacaklarını gösteren sonuçlar çeşitli araştırmalarla doğrulanmaktadır., ${ }^{9,16}$ Son zamanlarda pediatri hemşiresi olmayı planlayan öğrenci hemşirelerin sayısında ümit verici bir artış bildirilmektedir.

Literatürde çocuklarla oyun oynadığını/ çocuk oyunlarını bildiğini ifade eden ${ }^{17-19,26,27}$, çocuklarla ilgili haberleri takip eden/izleyen ${ }^{17,27}$, çocuk kitapları okuyan ${ }^{26,27}$, 
çocuk sevme düzeyleri yüksek bulundu. Çocuk kitapları okuyan, çocuk oyunlarını bilen öğrenci hemşirelerin bir çocuğun dünyasını anlama ve keşfetme olasılıklarının daha yüksek olduğu düşünülmektedir. Diğer bir deyişle, çocukla ilgili faaliyetler içinde olan öğrenci hemşireler çocuklarla daha kolay empati kurabilir ve tepkilerini tahmin edebilir. Öğrenci hemşirelerine ve pediatri hemşirelerine çocuk oyunları tanıtılarak, çocuklarla oynamaya ve çocuk kitapları okumaya teşvik edilerek çocukları sevme seviyeleri artırılabilir.

Tablo 3. Öğrencilerin bazı tanımlayıcı özelliklerine göre Barnett’s Çocuk Sevme Ölçeği ve Hemşireler İçin Duygusal Emek Davranışı Ölçeği puan ortalamaları (N=124)

\begin{tabular}{|c|c|c|c|c|c|}
\hline \multirow[b]{2}{*}{ Özellik } & \multirow[b]{2}{*}{$\begin{array}{l}\text { Barnett's Çocuk } \\
\text { Sevme Ölçeği }\end{array}$} & \multicolumn{4}{|c|}{ Hemşireler İçin Duygusal Emek Davranışı Ölçeği } \\
\hline & & $\begin{array}{l}\text { Derinlemesine } \\
\text { Davranış }\end{array}$ & $\begin{array}{l}\text { Yüzeyel } \\
\text { Davranış }\end{array}$ & $\begin{array}{l}\text { Samimi } \\
\text { Davranış }\end{array}$ & $\begin{array}{l}\text { Ölçek } \\
\text { Toplam }\end{array}$ \\
\hline & Ort. \pm SS & Ort. \pm SS & Ort. \pm SS & Ort. \pm SS & Ort. \pm SS \\
\hline \multicolumn{6}{|l|}{ Cinsiyet } \\
\hline $\mathrm{K} 1 \mathrm{z}$ & $83.95 \pm 11.31$ & $2,78 \pm 0,55$ & $2,80 \pm 0,52$ & $3,79 \pm 0,76$ & $2,91 \pm 0,44$ \\
\hline Erkek & $71,62 \pm 14,07$ & $3,12 \pm 0,46$ & $3,23 \pm 0,57$ & $3,19 \pm 0,94$ & $3,14 \pm 0,41$ \\
\hline & $\mathbf{p}=\mathbf{0 , 0 0 1}$ & $\mathrm{p}=\mathbf{0 , 0 0 1}$ & $\mathbf{p}<\mathbf{0 , 0 0 0}$ & $\mathbf{p}<\mathbf{0 , 0 0 0}$ & $\mathrm{p}=\mathbf{0 , 0 0 9}$ \\
\hline \multicolumn{6}{|l|}{ Mezun olunan lise } \\
\hline Düz lise & $79,58 \pm 13,85$ & $2,87 \pm 0,54$ & $2,94 \pm 0,58$ & $3,57 \pm 0,87$ & $2,96 \pm 0,45$ \\
\hline Sağlık Meslek lisesi & $\begin{array}{l}85,26 \pm 8,18 \\
\mathbf{p}=\mathbf{0 , 0 3 1}\end{array}$ & $\begin{array}{l}2,97 \pm 0,57 \\
\mathrm{p}=0,502\end{array}$ & $\begin{array}{l}2,84 \pm 0,52 \\
p=0,522\end{array}$ & $\begin{array}{l}3,93 \pm 0,65 \\
\mathrm{p}=0,131\end{array}$ & $\begin{array}{l}3,06 \pm 0,41 \\
p=0,445\end{array}$ \\
\hline \multicolumn{6}{|c|}{ Çocuk oyunlarını bilme durumu } \\
\hline Evet & $81,18 \pm 12,91$ & $2,86 \pm 0,55$ & $2,92 \pm 0,54$ & $3,66 \pm 0,83$ & $2,97 \pm 0,44$ \\
\hline Hayır & $\begin{array}{l}70,90 \pm 15,31 \\
\mathbf{p}=\mathbf{0 , 0 1 5}\end{array}$ & $\begin{array}{l}3,11 \pm 0,48 \\
\mathrm{p}=0,148\end{array}$ & $\begin{array}{l}3,03 \pm 0,82 \\
\mathrm{p}=0,564\end{array}$ & $\begin{array}{l}3,21 \pm 1,07 \\
\mathrm{p}=0,101\end{array}$ & $\begin{array}{l}3,09 \pm 0,46 \\
\mathrm{p}=0,394\end{array}$ \\
\hline \multicolumn{6}{|c|}{ Çocuk kitaplarını okuma durumu } \\
\hline Evet & $82,71 \pm 11,72$ & $2,88 \pm 0,55$ & $2,90 \pm 0,59$ & $3,79 \pm 0,78$ & $2,99 \pm 0,45$ \\
\hline Hayır & $\begin{array}{l}76,66 \pm 14,96 \\
\mathbf{p}=\mathbf{0 , 0 1 8}\end{array}$ & $\begin{array}{l}2,89 \pm 0,54 \\
\mathrm{p}=0,964\end{array}$ & $\begin{array}{l}2,97 \pm 0,54 \\
\mathrm{p}=0,535\end{array}$ & $\begin{array}{l}3,35 \pm 0,90 \\
\mathbf{p}=\mathbf{0 , 0 0 4}\end{array}$ & $\begin{array}{l}2,96 \pm 0,44 \\
p=0,703\end{array}$ \\
\hline \multicolumn{6}{|c|}{$\begin{array}{l}\text { Mezuniyet sonrası çocuk } \\
\text { servisinde çalışmayı isteme } \\
\text { durumu }\end{array}$} \\
\hline Evet & $85,18 \pm 9,89$ & $2,81 \pm 0,59$ & $2,81 \pm 0,45$ & $3,93 \pm 0,81$ & $2,94 \pm 0,45$ \\
\hline Hayır & $\begin{array}{l}77,17 \pm 14,42 \\
\mathbf{p}<\mathbf{0 , 0 0 0}\end{array}$ & $\begin{array}{l}2,93 \pm 0,51 \\
\mathrm{p}=0,207\end{array}$ & $\begin{array}{l}3,01 \pm 0,63 \\
\mathbf{p}=\mathbf{0 , 0 4 4}\end{array}$ & $\begin{array}{l}3,42 \pm 0,83 \\
\mathbf{p}=\mathbf{0 , 0 0 1}\end{array}$ & $\begin{array}{l}00 \pm 0,44 \\
\mathrm{p}=0,489\end{array}$ \\
\hline
\end{tabular}

Öğrencilerin klinik uygulama puanlarıyla; Barnett's Çocuk Sevme Ölçeği puanları arasında pozitif yönde orta düzeyde, 'Yüzeysel davranış' alt boyutu puanları ile arasında negatif yönde zayıf düzeyde ve 'Samimi davranış' alt boyut puanları ile arasında pozitif yönde yüksek düzeyde anlamlı bir ilişki olduğu saptandı $(\mathrm{p}<0,001)$. Öğrencilerin yaşları ile 'Samimi davranış' alt boyut puanları arasında negatif yönde zayıf düzeyde anlamlı bir ilişki olduğu belirlendi $(\mathrm{p}=0,03)$. Öğrencilerin Barnett's Çocuk Sevme Ölçeği puanlarıyla 'Yüzeysel davranış' alt boyut puanları arasında negatif yönde zayıf düzeyde, 'Samimi davranış' alt boyut puanları arasında pozitif yönde yüksek düzeyde anlamlı bir ilişki olduğu ve bu ilişkilerin ileri derecede anlamlı olduğu belirlendi $(\mathrm{p}<0,00)$ (Tablo 4).
Öğrencilerin çocuk sevme ölçeği puanları ile klinik uygulama puanlarının pozitif yönde ilişkili olduğu belirlendi. Çocuk alanında çalışan hemşirelerin en temel özelliklerinden biri çocukları sevmesidir., ${ }^{9,17}$ Hemşirelerin çocuk sevme durumları, çocuklarla daha sağlıklı ve kaliteli iletişim kurması, güvenli ve özenli davranmalarını etkileyen, çocuk bakım kalitesi için oldukça önemli bir unsurdur. ${ }^{18}$ Çalışmada öğrenci hemşirelerin çocuk sevme durumları klinik uygulama sürecinde öğrenme başarılarını artırmaktadır. Klinik uygulama puanı yükseldikçe samimi duygusal emek davranışının arttığı görülmektedir. Benzer ş̧ekilde literatürde duygusal emek davranış düzeyi ile çalışma performans durumu istatistiksel olarak birbirini etkileyen faktörler olarak belirlendi. ${ }^{28,29}$ Çocuk sevme ölçeği puanlanı 
artıkça yüzeysel emek davranışın azaldığı, çocuk sevme ile samimi duygusal emek davranışı arasında yüksek düzeyde pozitif iliş̧i saptand. Pediatri klinik uygulama başarısını arttırmak için öğrenci hemşirelerin çocuk sevme düzeyini etkileyebilecek faktörlere müdahale etmenin oldukça önemli olduğu görülmektedir.

Tablo 4. Öğrencileri bazı tanımlayıcı özellikleri, Barnett's Çocuk Sevme Ölçeği ve Hemşireler İçin Duygusal Emek Davranışı Ölçeği puanları ve arasındaki ilişki

$\begin{array}{lllllll}(1) & (2) & (3) & (4) & (5) & (6)\end{array}$

Değişken

(1) Uygulama performans1

(2) Yaş

(3) Barnett's Çocuk Sevme Ölçeği

(4) Hemşireler İçin Duygusal Emek Davranışı Ölçeği

(5) Derinlemesine davranış

(6) Yüzeyel davranış

(7) Samimi davranış
1

$-0,14$

0,11

$0,63-0,45$

$\mathbf{0 , 0 0} 0,61$

1

$\mathrm{p} \quad \mathbf{0 , 0 0} \quad 0,61 \quad 1$

$\begin{array}{lllll}\mathrm{r} & 0,36 & -0,07 & -0,01 & 1 \\ \mathrm{p} & 0,68 & 0,44 & 0,89 & 1\end{array}$

1

$\begin{array}{llllll}\mathrm{r} & -0,10 & 0,02 & -0,07 & 0,91 & 1 \\ \mathrm{p} & 0,26 & 0,79 & 0,43 & \mathbf{0 , 0 0} & 1\end{array}$

$\begin{array}{llllll}\text { r } & -0,28 & -0,04 & -0,34 & 0,73 & 0,54\end{array}$

$\begin{array}{llllll}\mathrm{p} & \mathbf{0 , 0 0} & 0,62 & \mathbf{0 , 0 0} & \mathbf{0 , 0 0} & \mathbf{0 , 0 0}\end{array}$

$\begin{array}{llllllll}\text { r } & 0,71 & \mathbf{- 0 , 1 8} & 0,63 & 0,27 & 0,03 & -0,06 & 1\end{array}$

$\begin{array}{lllllll}\mathrm{p} & \mathbf{0 , 0 0} & \mathbf{0 , 0 3} & \mathbf{0 , 0 0} & \mathbf{0 , 0 0} & 0,66 & 0,49\end{array}$

r: Pearson korelasyon katsayls

\section{SONUÇ VE ÖNERILER}

Çalışma sonuçları ışı̆̆ında, çalışmaya katılan öğrenci hemşirelerin çocukları sevme düzeyinin yüksek olduğu sonucuna varıldı. Çocuk sevme durumu cinsiyet, mezun olunan lise, çocuk oyunlarını bilme, çocuk kitaplarını okuma ve gelecekte çocuk hemşiresi olmayı planlama gibi bir dizi değişkenden etkilendi. Çocuk sevme düzeyinin klinik uygulama puanı ve duygusal emek davranışını etkilediği saptandı.

Hemşirelik mesleğinde özellikle lisans eğitimi süresince öğrencilerin çocuk sevme durumlarına olumlu katkı sağlayacak eğitim etkinliklerine yer verilmesi, duygusal emek davranışları, duyguların yönetimi konusunda farkındalık eğitim programlarının düzenlenmesi önerilmektedir. Ayrıca öğrenci hemşirelerin çocuk sevme durumunu hangi faktörlerin etkilediğini değerlendiren farklı, geniş çapta ve daha fazla araştırmaya gereksinim olduğu görülmektedir.

Sonuç olarak pediatri hemşireliğini kariyer tercihi olarak seçmeyi planlayan hemşirelik öğrencilerine profesyonel rehberlik sağlamak, çocukları sevme durumları ve ilgili değişkenleri ciddiye almak son derece önemli görülmektedir. 


\section{KAYNAKLAR}

1. Fisher, D. and King, L. (2013). "An Integrative Literature Review on Preparing Nursing Students through Simulation to Recognize and Respond to The Deteriorating Patient". Journal of Advanced Nursing, 69 (11), 2375-2388.

2. Dobrowolska, B, McGonagle, I, Jackson, C, Kane, R, Cabrera, E, Cooney-Miner, Di Cara, V, Pajnkihar, M, Prlic', N. and Palese, A. (2015). "Clinical Practice Models in Nursing Education: Implication for Students' Mobility". International Nursing Review, 62 (1), 36-46.

3. Moghaddam, H.R, Aghamohammadi, V, Jafari, M, Absalan, M. and Nasiri, K. (2020). "Challenges Faced by Nursing Students to Work With Nursing Personnel: A Qualitative Study". Adv Med Educ Pract, 22 (11), 313-319.

4. Oermann, M.H. and Lukomski, A.P. (2007). "Experiences of Students in Pediatric Nursing Clinical Courses”. Journal for Specialists in Pediatric Nursing, 6 (2), 65-72.

5. Liang, H.F., Wu, K.M. and Wang, Y.H. (2020). "Nursing Students' First-Time Experiences in Pediatric Clinical Practice in Taiwan: A qualitative study". Nurse Education Today, August, 91

6. Chen, J. (2010). "Morale and Role Strain of Undergraduate Nursing Students in A Pediatric Clinical Setting". J Nurs Res, 18 (2), 144-53.

7. Elçigil, A. and Yıldırım-Sarı, H. (2011). "Facilitating factors in Clinical Education in Nursing". Dokuz Eylul University School of Nursing Electronic Journal, 4 (2), $67-$ 71.

8. Altay, N. ve Törüner, E.K. (2014). “Öğrenci Hemşirelerin Klinik Stres Yaşama Ve Çocuk Sevme Durumlarının Belirlenmesi”. Dokuz Eylül Üniversitesi Hemşirelik Yüksekokulu Elektronik Dergisi, 7, 166-70.

9. Happell, B.M. (2000). "Love is All You Need"? Student Nurses' Interest in Working with Children". J Soc Pediatr Nurs, 5, 167-73

10. Mazhindu, D. (2009). "Ideal Nurses and Emotional Labour of Nursing". Nurse Researche, 16 (2), 91-94.

11. Gray, B. (2009). "The Emotional Labour of NursingDefining and Managing Emotions in Nursing Work". Nurse Education Today, 29, (2), 168-75.

12. Değirmenci, S.Ö. ve Baykal, Ü. (2017). "Hemşirelerin Duygusal Emek Davranıșı”. Sağlık ve Hemșirelik Yönetimi Dergisi, 3 (4), 143-147.

13. Yıldız, A.T. (2019). "Hemşirelerin Duygusal Emek Davranışları Ve Duygusal Emeğe İlişkin Görüşlerinin İncelenmesi" (Yüksek Lisans Tezi). Hacettepe Üniversitesi Sağlık Bilimleri Enstitüsü, Ankara.

14. Edwards, D, Burnard, P, Bennett, K. and Hebden, U. (2010). "A Longitudinal Study of Stress and Selfesteem in Student Nurses". Nurse Education Today, 30, 78-84.

15. Değirmenci, S. (2016). "Hemşireler İçin Duygusal Emek Davranıșı Ölçeğinin Geliştirilmesi”. (Doktora Tezi) İstanbul Üniversitesi/Sağlık Bilimleri Enstitüsü, İstanbul.

16. Duyan, V. ve Gelbal, S. (2008). "Barnett Çocuk Sevme Ölçeğini Türkçeye Uyarlama Çalıșması”. Eğitim ve Bilim, 33 (148), 40-8

17. Erdem, Y. ve Duyan, V. (2011). “A Determination of The Factors That Affect The Level of Pediatric Nurses' Liking of Children”. Turk J Med Sci, 41 (2), 295-305.

18. Kostak, M.A. (2013). "Hemşirelik ve Ebelik Öğrencilerinin Çocuk Sevme Durumları, Çocuk Sağlığı Ve Hastalıkları Hemşireliği Dersinin Çocuk Sevme Durumlarına Etkisi Ve Etkileyen Faktörler". Cumhuriyet Hemșirelik Dergisi, 2 (2), 50-6.
19. Bektaş, M, Ayar, D, Bektaş, İ, Selekoğlu, Y, Kudubeş, A.A. ve Altan, S.S. (2015). "Hemşirelik Öğrencilerinin Cocuk Sevme Durumlarını Etkileyen Faktörlerin Belirlenmesi”. The Journal of Pediatric Research, 2 (1), 3741.

20. Baran, G. ve Yılmaz, G. (2019). "Cocuk Sağlığı Ve Hastalıkları Hemşireliği Dersinin Uygulamasına Çıkan Hemșirelik Öğrencilerinin Cocuk Sevme Durumları Ve Etkileyen Faktörlerin İncelenmesi”. JAREN, 5 (2), 91-6.

21. Çalışır, H, Karataş, P, Turan, T. ve Ergin, D. (2020). "Pediatri Hemşirelerinde Cocuk Sevme İle Tükenmişlik, Eşduyum Yorgunluğu, Mesleki Tatmin Arasındaki İlişsił”. Türkiye Klinikleri J Nurs Sci, 12 (1), 30-6.

22. Koçak, B.T, Türkkan, N.Ü. ve Tuna, R. (2014) "Hemşirelik Öğrencilerinde Girişkenlik Düzeyi İle Duygusal Emek Davranışı Arasındaki İlişki”. Sağlık ve Hemşirelik Yönetimi Dergisi, 3 (1), 123-129.

23. Serin, S. (2014). Duygusal Emeğin Tükenmişlik Ve İş Tatminine Etkisi: Sağlı Sektöründe Bir Uygulama. (Yüksek Lisans Tezi). Türk Hava Kurumu Üniversitesi/Sosyal Bilimler Enstitüsü, Ankara.

24. Adeniji, O.G, Akanni, A.A. and Ekundayo, O.O. (2015) "Gender Difference in Emotional Labour among Nurses in Osun State", Nigeria. Gender and Behaviour, 13 (2), 67896794.

25. Al-Ma'aitah, R.M. and Gharaibeh, M.M. (2000). "Perception of Jordanian Male Nursing Students about Caring for Children in The Pediatric Units After Graduation". Journal of Pediatric Nursing, 15 (3), 198-203.

26. Güven, Ş.T., Kaya, A ve Dalgıç, A.İ. (2016). "Pediatric Nursing Students' Status of Liking of Children and Affecting Factors". International Journal on New Trends in Education and Their Implications, 7 (4), 50-56.

27. Gelbal, S. ve Duyan, V. (2010). “İlköğretim Öğretmenlerinin Cocuk Sevme Durumlarına Etki Eden Değişkenlerin İncelenmesi”. Hacettepe Üniversitesi Eğitim Fakültesi Dergisi, 38, 127-137.

28. Çağlıyan, V, Fındık, M. ve Doğanalp, B. (2013). "A Consideration on Emotional Labour, Burnout Syndrome and Job Performance: The Case of Health Institutions". Mediterranean Journal of Social Sciences, 4 (10), 532

29. Onay, M. (2011). "Çalışanın Sahip Olduğu Duygusa Zekasının Ve Duygusal Emeğinin, Görev Performansı Ve Bağlamsal Performans Üzerindeki Etkisi”. Ege Akademik Bakış, 11 (4), 587. 